\title{
KINERJA KEUANGAN PROVINSI KEPULAUAN BANGKA BELITUNG DITINJAU DARI DERAJAT KEMANDIRIAN, KETERGANTUNGAN, DAN DESENTRALISASI FISKAL
}

\author{
Nizwan Zukhri \\ Universitas Bangka Belitung \\ Alamat Korespondensi: nizwan_ubb@yahoo.com
}

\begin{abstract}
Bangka Belitung Islands is a province that was born in the era of regional autonomy. This province is demanded to be able to manage finances well to achieve regional independence. This paper aims to analyze the degree of independence, degree of dependency, and degree of fiscal decentralization of the Bangka Belitung Islands Province. The data used is the realization data of the Bangka Belitung Islands Province Regional Budget for the 2016-2018 fiscal year. This study uses a quantitative descriptive analysis method based on local government financial ratios in the form of independence ratios, dependency ratios, and fiscal decentralization ratios. The results showed that from the aspect of independence, the financial capability of the Bangka Belitung Islands Province was in the low category (46.09-49.83 percent) with a consultative relationship pattern. Based on the degree of regional dependency in the very high category (61.05-68.41 percent), whereas in terms of the degree of fiscal decentralization, the financial capability of the Bangka Belitung Islands Province is in the moderate-sufficient category (29.47-33.26 percent).
\end{abstract}

KATA KUNCI:

Kinerja Keuangan, Derajat Kemandirian, Derajat Ketergantungan, Derajat Desentralisasi Fiskal

\begin{abstract}
ABSTRAK
Kepulauan Bangka Belitung merupakan provinsi yang lahir di era otonomi daerah. Provinsi ini dituntut untuk mampu mengelola keuangan dengan baik dalam rangka mencapai kemandirian daerah. Paper ini bertujuan untuk menganalisis derajat kemandirian, ketergantungan, dan desentralisasi fiskal Provinsi Kepulauan Bangka Belitung. Data yang digunakan adalah data APBD Provinsi Kepulauan Bangka Belitung tahun anggaran 2016-2018. Penelitian ini menggunakan metode analisis deskriptif kuantitatif berdasarkan rasio-rasio keuangan pemerintah daerah berupa rasio kemandirian, rasio ketergantungan, dan rasio desentralisasi fiskal. Hasil penelitian menunjukkan bahwa dari aspek kemandirian, kemampuan keuangan Provinsi Kepulauan Bangka Belitung berada pada kategori rendah dengan pola hubungan konsultatif. Berdasarkan derajat ketergantungan daerah berada dalam kategori sangat tinggi, sedangkan ditinjau dari derajat desentralisasi fiskal, kemampuan keuangan Provinsi Kepulauan Bangka Belitung berada dalam kategori sedang sampai dengan cukup $(29,47-33,26$ persen$)$.
\end{abstract}

\section{KLASIFIKASI JEL:}

H72

CARA MENGUTIP:

Zukhri, N. (2020). Kinerja keuangan Provinsi Kepulauan Bangka Belitung ditinjau dari derajat kemandirian, ketergantungan, dan desentralisasi fiskal. Indonesian Treasury Review: Jurnal Perbendaharaan, Keuangan Negara dan Kebijakan Publik, 5(2), 143-149. 


\section{PENDAHULUAN}

\subsection{Latar Belakang}

Kepulauan Bangka Belitung merupakan provinsi yang lahir di era otonomi daerah. Provinsi ini dituntut untuk mampu mengelola keuangan dengan baik dalam rangka mencapai kemandirian daerah. Sebagai perpanjangan tangan dari pemerintah pusat, pemerintah daerah yang merupakan subsistem pemerintahan negara dituntut untuk mampu meningkatkan efisiensi dan efektifitas dalam penyelenggaraan pemerintahan dan pelayanan kepada masyarakat.

Berdasarkan Undang-Undang Nomor 32 tahun 2004 tentang Pemerintahan Daerah, dan Undang-Undang Nomor 33 tahun 2004 tentang Perimbangan Keuangan antara Pemerintah Pusat dan Pemerintah Daerah. Prinsip dasar pemberian otonomi kepada provinsi, dan kabupaten/kota didasarkan pada pertimbangan bahwa daerah yang lebih mengetahui kebutuhan dan standar pelayanan bagi masyarakat di daerahnya. Sebagai suatu daerah otonomi yang dibentuk berdasarkan Undang-Undang Republik Indonesia Nomor 27 Tahun 2000, Provinsi Kepulauan Bangka Belitung dituntut untuk mampu mengelola semua sumber daya yang ada secara optimal, termasuk pengelolaan sumber daya keuangan secara mandiri.

Tujuan pelaksanaan otonomi adalah untuk meningkatkan kemandirian daerah dan tujuan dilaksanakannya desentralisasi fiskal adalah untuk mengurangi ketergantungan fiskal daerah terhadap pemerintah pusat (Mahmudi, 2010, hal. 2). Kemandirian suatu daerah dalam bidang keuangan sangat tergantung pada kemampuan daerah dalam mengelola Pendapatan Asli Daerah (PAD). Oleh karena itu suatu daerah provinsi maupun kabupaten/kota dituntut untuk mampu meningkatkan kemampuannya dalam menghasilkan PAD.

Gambar 1.1 menunjukkan perkembangan Pendapatan Asli Daerah (PAD) Provinsi Kepulauan Belitung pada tahun 2016-2018. Dalam tiga tahun terakhir, PAD Provinsi Kepulauan Bangka Belitung cenderung mengalami peningkatan, di mana pada tahun 2016 jumlah PAD Provinsi Kepulauan Bangka Belitung sebesar Rp.574.456.474.397,80 dan mengalami peningkatan pada tahun 2017 menjadi Rp. 709.832.181.818,00, dan kembali mengalami peningkatan pada tahun 2018 menjadi Rp. 850.441.774.831,35.
Gambar 1.1 Perkembangan PAD Provinsi Kepulauan Bangka Belitung Tahun 2016-2018

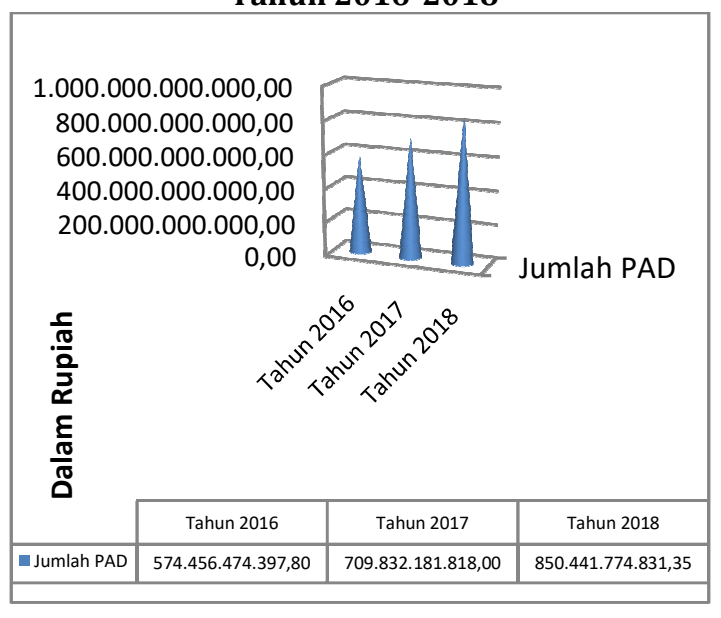

Sumber: Kanwil Perbendaharaan Negara Provinsi Kepulauan Bangka Belitung, 2019

PAD seharusnya merupakan sumber pendapatan utama yang berkontribusi terhadap kinerja keuangan daerah. Dengan jumlah PAD yang sangat terbatas, sementara untuk membiayai berbagai kegiatan dalam rangka meningkatkan pelayanan dan kesejahteraan masyarakat diperlukan dana yang besar, maka pemerintah daerah membutuhkan sumber dana lain di luar PAD. Salah satu sumber dana tersebut adalah dana yang berasal dari bantuan dari pemerintah pusat.

Penelitian tentang kinerja keuangan daerah sudah pernah dilakukan oleh Lubis \& Hafni (2017, hal. 34), hasil penelitiannya menunjukkan bahwa tingkat kemandirian pemerintah daerah Kabupaten Labuhan Batu masih relatif rendah. Hasil yang berbeda ditemukan oleh Nufus, Hadi, \& Awaluddin. (2017, hal. 146), yang menemukan bahwa tingkat kemandirian Kota Tangerang Selatan berada pada kategori sangat bagus sekali.

Bertolak dari permasalahan tersebut, menjadi menarik untuk dilakukan kajian bagaimana kinerja keuangan daerah Provinsi Kepulauan Bangka Belitung ditinjau dari derajat kemandirian, derajat ketergantungan, dan derajat desentralisasi fiskal.

\section{LANDASAN TEORI 2.1 Otonomi Daerah}

Berdasarkan Undang-Undang Negara Republik Indonesia Nomor 32 Tahun 2004, otonomi daerah adalah hak, wewenang, dan kewajiban daerah otonom untuk mengatur dan mengurus sendiri urusan pemerintahan dan kepentingan masyarakat setempat sesuai dengan peraturan perundang-undangan. Otonomi daerah memberi kewenangan kepada pemerintah daerah 
secara lebih luas untuk mengatur sendiri daerahnya. Pemerintah provinsi atau kabupaten/kota harus mampu menciptakan inovasi dan kreasi dalam mengelola sumbersumber keuangan daerah untuk memberikan pelayanan terbaik kepada masyarakat. Menurut Pekei (2016, hal. 7), pemberian kewenangan yang lebih luas mewajibkan pemerintah provinsi dan kabupaten/kota untuk meningkatkan pelayanan, dan kesejahteraan masyarakat. Otonomi daerah juga tidak terlepas dari Undang-Undang Republik Indonesia Nomor 33 tahun 2004 yang mengatur tentang perimbangan keuangan antara pemerintah pusat dan daerah. Perimbangan keuangan antara pemerintah pusat dan pemerintah daerah merupakan sistem yang menyeluruh dan terpadu dalam pendanaan berdasarkan asas desentralisasi (Pekei, 2016, hal. 7).

\subsection{Derajat Kemandirian, Derajat Ketergantungan, dan Derajat Desentralisasi Fiskal}

Halim (2011, hal. 253) mengemukakan bahwa kemandirian keuangan daerah menunjukkan kemampuan pemerintah daerah dalam membiayai sendiri kegiatan pemerintahan, pembangunan, dan pelayanan kepada masyarakat yang telah membayar pajak dan retribusi sebagai sumber pendapatan yang diperlukan daerah. Berkaitan dengan masalah kemandirian, Undang-Undang Nomor 32 tahun 2004 pasal 1 ayat 7 menyebutkan bahwa desentralisasi adalah penyerahan wewenang pemerintahan oleh pemerintah pusat kepada daerah otonom untuk mengatur dan mengurus urusan pemerintahan dalam sistem Negara Kesatuan Republik Indonesia.

Derajat desentralisasi fiskal menunjukkan perbandingan antara jumlah Pendapatan Asli Daerah dengan Total Pendapatan Daerah, dalam kaitannya dengan desentralisasi fiskal, Mahmudi (2016, hal. 140) mengemukakan bahwa semakin tinggi kontribusi Pendapatan Asli Daerah (PAD) terhadap Total Pendapatan Daerah (TPD), maka akan semakin tinggi kemampuan pemerintah daerah dalam penyelenggaraan desentralisasi.

\subsection{Kerangka Pemikiran \\ Gambar 2.1 Kerangka Pemikiran}

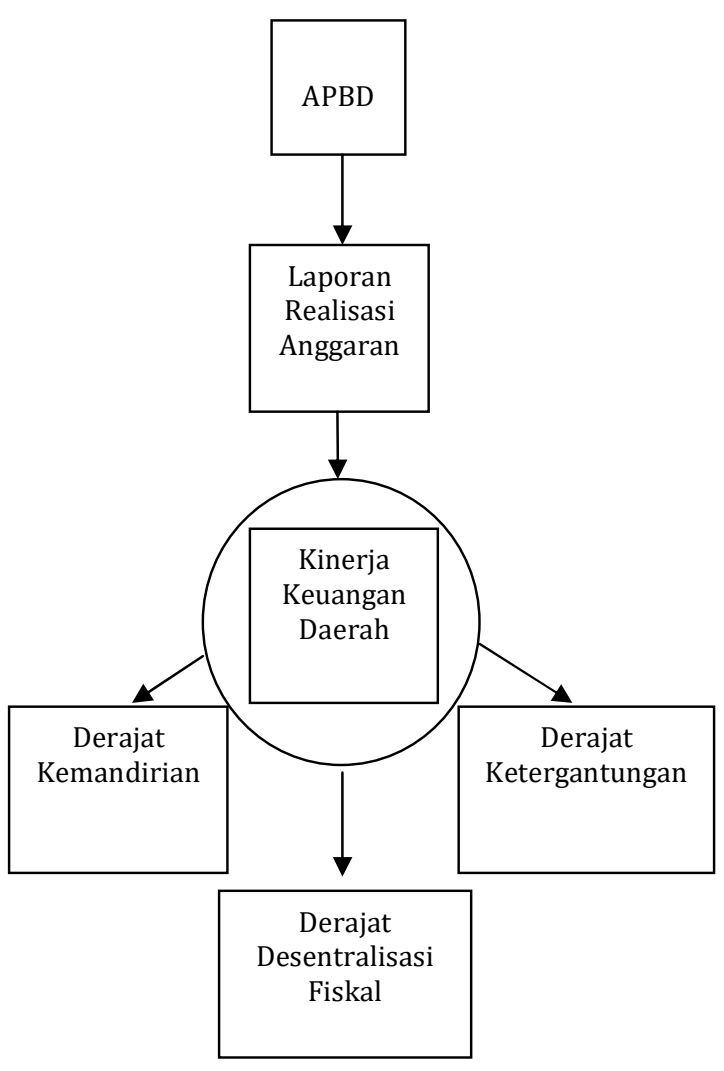

\section{METODOLOGI PENELITIAN}

Jenis penelitian yang dilakukan menggunakan metode deskriptif kuantitatif dengan menggunakan alat-alat analisa rasio keuangan daerah yaitu: rasio kemandirian, rasio ketergantungan, dan rasio derajat desentralisasi fiskal. Obyek dalam penelitian ini adalah Laporan Keuangan Daerah Provinsi Kepulauan Bangka Belitung yang tercermin dalam Laporan Anggaran Pendapatan dan Belanja Daerah Provinsi Kepulauan Bangka Belitung tahun 2016-2018.

Secara lebih terperinci alat rasio keuangan yang digunakan dalam penelitian ini adalah:

1. Rasio Kemandirian, yang menunjukkan perbandingan antara Pendapatan Asli daerah (PAD) dengan bantuan pemerintah pusat dan pinjaman.

Untuk melihat kemampuan kemampuan keuangan daerah yang diukur dengan variabel kemandirian dan kategori pola hubungan antara pemerintah pusat dan daerah sebagaimana disajikan pada Tabel 3.1. 
Tabel 3.1

Pola Hubungan dan Tingkat Kemampuan Daerah

\begin{tabular}{|c|c|c|}
\hline $\begin{array}{c}\text { Kemampuan } \\
\text { Keuangan }\end{array}$ & $\begin{array}{c}\text { Kemandirian } \\
\text { (\%) }\end{array}$ & $\begin{array}{c}\text { Pola } \\
\text { Hubungan }\end{array}$ \\
\hline $\begin{array}{c}\text { Rendah } \\
\text { Sekali }\end{array}$ & $0-25$ & Instruktif \\
\hline Rendah & $25-50$ & Konsultatif \\
\hline Sedang & $50-75$ & Partisipatif \\
\hline Tinggi & $75-100$ & Delegatif \\
\hline Sumber: Halim (2007)
\end{tabular}

2. Rasio Derajat Ketergantungan, yang menunjukkan perbandingan jumlah pendapatan transfer dari pemerintah pusat dengan total penerimaan daerah.

Untuk melihat derajat ketergantungan digunakan kriteria sebagaimana terdapat pada Tabel 3.2 .

Tabel 3.2

Kriteria Penilaian Ketergantungan Keuangan Daerah

\begin{tabular}{|c|c|}
\hline Ketergantungan (\%) & Kategori \\
\hline $0,00-10,00$ & Sangat Rendah \\
\hline $10,01-20,00$ & Rendah \\
\hline $20,01-30,00$ & Sedang \\
\hline $30,01-40,00$ & Cukup Tinggi \\
\hline $40,01-50,00$ & Tinggi \\
\hline$>50,00$ & Sangat Tinggi \\
\hline
\end{tabular}

Sumber: Bangga (2017)

3. Rasio Derajat Desentralisasi Fiskal, yang menunjukkan perbandingan antara Pendapatan Asli Daerah (PAD) dengan Total Pendapatan Daerah (TPD).

Untuk melihat derajat desentralisasi fiskal Provinsi Kepulauan Bangka Belitung digunakan skala interval pada Tabel 3.3.

Tabel 3.3

Skala Interval Derajat Desentralisasi Fiskal

\begin{tabular}{|c|c|}
\hline $\begin{array}{c}\text { Derajat } \\
\text { Desentraliasi } \\
\text { fiskal }\end{array}$ & Keterangan \\
\hline $0,00-10,00$ & Sangat Kurang \\
\hline $10,00-20,00$ & Kurang \\
\hline $20,01-30,00$ & Sedang \\
\hline $30,01-40,00$ & Cukup \\
\hline $40,01-50,00$ & Baik \\
\hline$>50,00$ & Sangat Baik \\
\hline
\end{tabular}

Sumber: Hanafi, dkk (2005)

\section{HASIL PENELITIAN}

Dalam pelaksanaan otonomi, provinsi, atau kabupaten/kota dituntut untuk mampu menggali dan mengelola sumber daya keuangan dalam rangka membiayai kegiatan-kegiatan pembangunan. Untuk itu daerah dituntut untuk mampu menggali sumber-sumber Pendapatan Asli Daerah (PAD). Penelitian ini mengkaji kemampuan keuangan Provinsi Kepulauan Bangka Belitung yang dilihat berdasarkan derajat kemandirian, derajat ketergantungan, dan derajat desentralisasi fiskal, oleh karena itu pembahasan dalam penelitian ini akan dikelompokkan kedalam tiga aspek tersebut.

\subsection{Derajat Kemandirian}

Derajat kemandirian menunjukkan seberapa besar kemampuan keuangan daerah dalam membiayai sendiri kegiatannya dengan dana yang diperoleh dari Pendapatan Asli daerah dibandingkan dengan dana yang berasal dari bantuan pemerintah pusat dan pinjaman. Meningkatkan kemandirian daerah merupakan salah satu prioritas utama daerah (Yulianti, 2018, hal. 268). Kinerja keuangan daerah Provinsi Kepulauan Bangka Belitung berdasarkan derajat kemandirian disajikan pada Tabel 4.1.

Tabel 4.1

Rasio Kemandirian Keuangan Daerah Provinsi Kepulauan Bangka Belitung Tahun 2016-2018

\begin{tabular}{|c|c|c|c|}
\hline Tahun & PAD & $\begin{array}{c}\text { Bantuan } \\
\text { Pemerintah Pusat }\end{array}$ & $\begin{array}{c}\text { Persentase } \\
\text { Kemandiri- } \\
\text { an }\end{array}$ \\
\hline 2016 & $574.456 .474 .397,80$ & $1.190 .085 .279 .783,00$ & 48,27 \\
\hline 2017 & $709.832 .181 .818,00$ & $1.539 .960 .002 .502,00$ & 46,09 \\
\hline 2018 & $850.441 .774 .831,35$ & $1.706 .535 .937 .093,00$ & 49,83 \\
\hline
\end{tabular}

Sumber: Kanwil DJPBN Provinsi Kepulauan Bangka Belitung

Berdasarkan Tabel 4.1 dapat dilihat bahwa kemandirian keuangan daerah Provinsi Kepulauan Bangka Belitung setiap tahunnya mengalami fluktuasi. Pada tahun 2016 kemandirian keuangan sebesar 48,27 persen yang berarti berada pada level rendah dengan pola hubungan konsultatif. Pada tahun 2017 kemandirian keuangan mengalami penurunan dengan persentase kemandirian sebesar 46,09 persen yang berarti mengalami penurunan dibandingkan pada tahun 2016 dan tetap berada pada level rendah dengan pola hubungan konsultatif. Pada tahun 2018, kemandirian keuangan mengalami kenaikan dengan persentase kemandiriaan sebesar 49,83 
persen yang berarti masih berada pada level rendah dengan pola hubungan konsultatif.

Kinerja keuangan daerah Provinsi Kepulauan Bangka Belitung berdasarkan aspek kemandirian menunjukkan bahwa tingkat kemandirian keuangan belum berada pada level seperti yang diharapkan. Pada tahun 2016 kemampuan keuangan Provinsi Kepulauan Bangka Belitung berada pada level rendah dengan persentase sebesar 48,27 persen yang berarti berada pada pola hubungan konsultatif. Pada kondisi ini, Pendapatan Asli Daerah Provinsi Kepulauan Bangka Belitung memberikan kontribusi terhadap Anggaran Pendapatan dan Belanja Daerah (APBD) sebesar 48,27 persen, sedangkan sebesar 51,73 persen dari bantuan pemerintah pusat dan pinjaman. Pada tahun 2017 rasio kemandirian keuangan daerah Provinsi Kepulauan Bangka Belitung mengalami penurunan kinerja yang berada pada level rendah dengan persentase sebesar 46,09 persen dengan pola hubungan konsultatif.

Berdasarkan kajian pada APBD Provinsi Kepulauan Bangka Belitung penurunan rasio tersebut disebabkan terjadinya penurunan dari PAD, sementara jumlah bantuan pemerintah pusat mengalami peningkatan dibandingkan pada tahun 2016. Pada tahun 2018 rasio kemandirian keuangan daerah sebesar 49,83 persen yang berarti mengalami peningkatan dibandingkan dua tahun sebelumnya yang berarti masih tetap berada pada level rendah dengan pola hubungan konsultatif.

Dari hasil telaah terhadap APBD Provinsi Kepulauan Bangka Belitung penurunan rasio kemandirian tersebut disebabkan adanya peningkatan yang cukup signifikan dari bantuan pemerintah pusat. Peningkatan PAD yang terjadi, tidak sebesar peningkatan dana bantuan dari pemerintah pusat. Andriani \& Wahid (2018, hal. 35) mengungkapkan bahwa tingkat kemandirian keuangan daerah sangat tergantung pada kinerja PAD. Hasil penelitian Mandey \& Rotinsulu (2015, hal. 836), menunjukkan bahwa kinerja keuangan Kota Bitung yang diukur dari rasio kemandirian berada pada kategori masih rendah. Penelitian lain yang dilakukan oleh Sulianti \& Ika (2012, hal. 134) yang melakukan penelitian tentang perbandingan kinerja keuangan Provinsi Daerah Istimewa Yogyakarta menemukan hasil bahwa tidak terdapat peningkatan rasio kemandirian setelah otonomi daerah. Ketidakmampuan dalam mengelola PAD menyebabkan masih rendahnya tingkat kemandirian (Tamboto, Morasa, \& Mawikere, 2014, hal. 765). Demikian juga hasil penelitian Vurry, Suwendra, \& Yudiaatmaja (2014, hal. 7), menunjukkan bahwa rasio kemandirian keuangan Kabupaten Buleleng berada dalam kategori rendah sekali. Hasil yang berbeda diungkapkan Sulistyo (2018, hal. 48), kinerja keuangan Kalimantan timur menunjukkan hasil yang baik jika dilihat dari aspek kemandirian.

\subsection{Derajat Ketergantungan}

Derajat ketergantungan menunjukkan perbandingan antara jumlah pendapatan transfer yang diterima oleh pemerintah daerah dengan total penerimaan daerah. Kinerja keuangan daerah Provinsi Kepulauan Bangka Belitung berdasarkan derajat ketergantungan disajikan pada Tabel 4.2.

\section{Tabel 4.2}

\section{Derajat Ketergantungan Keuangan Daerah Provinsi Kepulauan Bangka Belitung} Tahun 2016-2018

\begin{tabular}{|c|c|c|c|}
\hline Tahun & $\begin{array}{c}\text { Pendapatan } \\
\text { Transfer/Bantuan }\end{array}$ & $\begin{array}{c}\text { Total Pendapatan } \\
\text { Daerah }\end{array}$ & $\begin{array}{c}\text { Persentase } \\
\text { Derajat } \\
\text { Ketergan- } \\
\text { tungan }\end{array}$ \\
\hline 2016 & $1.190 .085 .279 .783,00$ & $1.949 .460 .754 .180,80$ & 61,05 \\
\hline 2017 & $1.539 .960 .002 .502,00$ & $2.251 .024 .652 .420,00$ & 68,41 \\
\hline 2018 & $1.706 .535 .937 .093,00$ & $2.556 .977 .711 .924,35$ & 66,74 \\
\hline
\end{tabular}

Sumber: Kanwil DJPBN Provinsi Kepulauan Bangka Belitung

Berdasarkan Tabel 4.2 dapat dilihat bahwa derajat ketergantungan keuangan daerah Provinsi Kepulauan Bangka Belitung pada periode tahun 2016-2018 mengalami fluktuasi. Pada tahun 2016 derajat ketergantungan keuangan daerah sebesar 61,05 persen. Pada tahun 2017 derajat ketergantungan keuangan mengalami peningkatan dengan persentase ketergantungan sebesar 68,41 persen. Pada tahun 2018, derajat ketergantungan keuangan mengalami penurunan dengan persentase ketergantungan sebesar 66,74 persen. Dengan tingkat ketergantungan antara 61,0568,41 persen dapat dikatakan bahwa dalam periode 2016-2018 tingkat ketergantungan keuangan daerah Provinsi Kepulauan Bangka Belitung berada dalam kategori tingkat ketergantungan yang sangat tinggi. Hasil penelitian ini sejalan dengan penelitian Febiandani \& Suseno (2016, hal. 219) yang menyatakan bahwa kemandirian keuangan daerah di Provinsi Jawa Tengah juga masih berada di level yang kurang baik yang berarti juga masih tergantung kepada pemerintah pusat. Demikian juga hasil penelitian Prastiwi, Arfan, \& Darwanis (2016, hal. 83) menemukan bahwa tingkat ketergantungan terhadap dana eksternal kabupaten dan kota di Provinsi Aceh masih sangat tinggi. Penelitian lain (Mokodompit, Pangemanan, \& Elim, 2014, hal. 1527) menunjukkan bahwa rasio ketergantungan keuangan daerah Kota Kotamobagu terhadap pemerintah pusat dan provinsi masih sangat tinggi. 


\subsection{Derajat Desentralisasi Fiskal}

Derajat desentralisasi menggambarkan seberapa besar kemampuan keuangan daerah dalam membiayai kegiatannya yang diukur dengan membandingkan jumlah Pendapatan Asli Daerah (PAD) dengan Total Pendapatan Daerah (TPD). Kinerja keuangan daerah berdasarkan derajat desentralisasi fiskal dapat dilihat pada Tabel 4.3.

Tabel 4.3

Derajat Desentralisasi Fiskal Provinsi Kepulauan Bangka Belitung Tahun 2016-2018

\begin{tabular}{|c|c|c|c|}
\hline Tahun & $\begin{array}{c}\text { Pendapatan Asli } \\
\text { Daerah }\end{array}$ & $\begin{array}{c}\text { Total Pendapatan } \\
\text { Daerah }\end{array}$ & $\begin{array}{c}\text { Persentase } \\
\text { Derajat } \\
\text { Desentrali } \\
\text { sasi Fiskal }\end{array}$ \\
\hline 2016 & $574.456 .474 .397,80$ & $1.949 .460 .754 .180,80$ & 29,47 \\
\hline 2017 & $709.832 .181 .818,00$ & $2.251 .024 .652 .420,00$ & 31,53 \\
\hline 2018 & $850.441 .774 .831,35$ & $2.556 .977 .711 .924,35$ & 33,26 \\
\hline
\end{tabular}

Sumber: Kanwil DJPBN Provinsi Kepulauan Bangka Belitung

Berdasarkan Tabel 4.3 dapat dilihat bahwa kemampuan keuangan daerah Provinsi Kepulauan Bangka Belitung dalam membiayai kegiatannya berdasarkan aspek derajat desentralisasi fiskal dari tahun 2016-2018 berfluktuasi. Pada tahun 2016 derajat desentralisasi fiskal Provinsi Kepulauan Bangka Belitung berada pada level sedang dengan persentase sebesar 29,47 persen. Pada tahun 2017 derajat desentralisasi tersebut mengalami kenaikan ke level cukup dengan persentase sebesar 31,53 persen. Pada tahun 2018 derajat desentralisasi fiskal Provinsi Kepulauan Bangka Belitung kembali mengalami peningkatan ke level cukup dengan persentase sebesar 33,26 persen. Febiandani \& Suseno (2016, hal. 217) mengungkapkan bahwa adanya desentralisasi fiskal akan dapat menciptakan kemandirian daerah dan dapat mengurangi ketergantungan pemerintah daerah terhadap pemerintah pusat.

\section{KESIMPULAN DAN SARAN}

\subsection{Kesimpulan}

Berdasarkan hasil penelitian dan pembahasan mengenai Kinerja Keuangan Provinsi Kepulauan Bangka Belitung Ditinjau dari Derajat Kemandirian, Derajat Ketergantungan, dan Derajat Desentralisasi Fiskal dapat disimpulkan bahwa tingkat kemandirian kemampuan keuangan Provinsi Kepulauan Bangka Belitung pada tahun 2016-2018 berada pada level rendah yang berarti berada pada pola hubungan konsultatif.

Tingkat ketergantungan Keuangan Provinsi Kepulauan Bangka Belitung pada tahun 2016-2018 berada pada kisaran 61,05-68,41 persen atau berada pada kategori sangat tinggi atau sangat tergantung pada dana dari pemerintah pusat.
Derajat desentralisasi fiskal Provinsi Kepulauan Bangka Belitung pada tahun 2016-2018 berada pada skala interval 29,47-33,26 persen yang berarti berada pada kategori cukup dan sedang.

\subsection{Saran}

Pemerintah Provinsi Kepulauan Bangka Belitung harus melakukan tindakan-tindakan secara komprehensif dalam upaya meningkatkan Pendapatan Asli Daerah dengan melakukan diversifikasi sumber-sumber Pendapatan Asli Daerah sehingga tidak lagi tergantung kepada sumber pendapatan yang berasal dari sektor pertambangan. Upaya mengembangkan pariwisata beserta sektor-sektor pendukungnya harus dilakukan secara masif dan bersinergi dengan stakeholder-satkeholder terkait.

\section{IMPLIKASI DAN KETERBATASAN}

Implikasi dari penelitian ini menunjukkan bahwa Pemerintah Daerah Provinsi Kepulauan Bangka Belitung harus melakukan langkah-langkah strategis dalam upaya meningkatkan rasio kemandirian yang akan berdampak terhadap penurunan rasio ketergantungan, langkah lainnya adalah dengan meningkatkan rasio derajat desentralisasi fiskal. Keterbatasan dari penelitian ini adalah hanya melihat kinerja keuangan yang didasarkan kepada tiga aspek yaitu aspek kemandirian, aspek ketergantungan, dan derajat desentralisasi fiskal. Data yang digunakan terbatas hanya tiga tahun yaitu data dari tahun 2016 sampai dengan 2018. Untuk itu perlu dilakukan penelitian lanjutan dengan memasukkan aspekaspek lain seperti rasio keserasian, derajat kapasitas fiskal, dan aspek-aspek lainnya.

\section{PENGHARGAAN}

Pada kesempatan ini penulis mengucapkan terima kasih kepada berbagai pihak yang telah memberikan kontribusi dalam penyelesaian karya tulis ilmiah ini terutama kepada teman-teman dosen di lingkungan Universitas Bangka Belitung, serta Kanwil DJPBN Provinsi Kepulauan Bangka Belitung. Ucapan terima kasih juga penulis tujukan kepada Kementerian Keuangan khususnya Jurnal Indonesian Treasury Review yang telah memberi kesempatan penulis untuk dapat mempresentasikan karya tulis ini. 


\section{REFERENSI}

Andriani, R. N. R., \& Wahid, N. N. (2018). Pengaruh pendapatan asli daerah dan dana perimbangan terhadap kemandirian keuangan daerah (studi kasus pada pemerintah kota Tasikmalaya tahun 2006-2015). Jurnal Akuntansi, 13(1), 30-39.

Bangga, W. (2017). Administrasi keuangan negara dan daerah. Bogor: Ghalia Indonesia.

Dewi, P. K., \& Hafni, N. (2017). Analisis rasio keuangan untuk mengukur kinerja keuangan pemerintah daerah Kabupaten Labuhan Batu tahun anggaran 2011-2013. Jurnal Kitabah, 1(1), 21-45.

Febiandani, R., \& Suseno, D. A. (2016). Analisis hubungan kemandirian keuangan daerah dan ketergantungan daerah terhadap pengangguran dan kemiskinan. Economic Development Analysis Journal, 5(2), 217-225.

Halim, A. (2013). Akuntansi keuangan daerah. Yogyakarta: Salemba Empat.

Mahmudi. (2010). Manajemen keuangan daerah. Jakarta: Erlangga.

Mahmudi. (2016). Analisis laporan keuangan pemerintah daerah. Yogyakarta: UPP STIM YKPN.

Mandey, K., \& Oldy, R. T. (2015). Analisis kinerja pendapatan asli daerah dikaitkan dengan belanja daerah pada pemerintah Kota Bitung. Jurnal EMBA: Jurnal Riset Ekonomi, Manajemen, Bisnis, dan Akuntansi, 3(3), 827-838.

Mokodompit, P. S., Pangemanan, S., \& Elim, I. (2014). Analisis kinerja keuangan pemerintah daerah Kota Kotamobagu. Jurnal EMBA: Jurnal Riset Ekonomi, Manajemen, Bisnis, dan Akuntansi, 2(2), 1521-1527.

Nufus, H., Hadi, S., \& Awaluddin, M. (2017). Analysis of financial performance of local government through south tangerang calculation of realization regional budget. European Journal of Business and Management, 9(3), 136-146.

Pekei, B. (2016). Konsep dan analisis efektivitas pengelolaan keuangan di era otonomi. Jakarta: Taushia.
Prastiwi, T., Arfan, \& Darwanis. (2016). Analisis kinerja pemerintah daerah kabupaten dan kota di Provinsi Aceh berdasarkan rasio kemandirian keuangan daerah. Buletin Ekonomi, 14(1), 79-84.

Sulianti, S., \& Ika, S. R. (2012). Perbandingan kinerja keuangan Daerah Istimewa Yogyakarta sebelum dan sesudah otonomi daerah. Jurnal Bisnis dan Ekonomi, 3(2), 123-138.

Sulistyo, A. T. (2018). Analisis kinerja keuangan pemerintah Provinsi Kalimantan Timur. Indonesian Treasury Review: Jurnal Perbendaharaan, Keuangan Negara dan Kebijakan Publik, 3(1), 43-59.

Tamboto, T., Morasa, J., \& Mawikere, L. (2014). Analisis kemampuan keuangan daerah dalam masa otonomi daerah pada Kabupaten Minahasa Tenggara. Jurnal EMBA: Jurnal Riset Ekonomi, Manajemen, Bisnis, dan Akuntansi, 2(2), 755-767.

Undang-Undang Republik Indonesia Nomor 27 Tahun 2000 Tentang Pembentukan Provinsi Kepulauan Bangka Belitung.

Undang-undang Republik Indonesia Nomor 32 tahun 2004 tentang Pemerintahan Daerah.

Undang-undang Republik Indonesia Nomor 33 tahun 2004 tentang Perimbangan Keuangan antara Pemerintah Pusat dan Pemerintah Daerah.

Vurry, A. N., Suwendra, I. W., \& Yudiaatmaja, F. (2014). Analisis kemampuan keuangan daerah dan trend pada pemerintah Kabupaten Buleleng tahun anggaran 2004-2013. Jurnal Manajemen Indonesia, 2(1), 1-8.

Wahyuni, E., \& Lilis, A. (2018). Pengaruh kinerja pendapatan asli daerah, belanja modal, belanja pegawai terhadap tingkat kemandirian keuangan daerah. Jurnal Ilmu dan Riset Akuntansi, 7(6), 1-16.

Yulianti, A. D. (2018). Strategi penerbitan obligasi daerah sebagai alternatif sumber penerimaan daerah di Provinsi Jawa Tengah. Economics Development Analysis Journal, 7(3), 268-275. 